\title{
Recognition and penetration of the HIV-1 Env glycan shield by potent broadly neutralizing antibodies
}

\author{
J Julien ${ }^{8}$, L Kong ${ }^{8}$, R Pejchal ${ }^{8}$, R Khayat ${ }^{1}$, J Lee ${ }^{1}$, RS Stanfield ${ }^{8}$, LM Walker ${ }^{2}$, KJ Doores ${ }^{3}$, E Folkowska ${ }^{3}$, P Poignard ${ }^{2}$, \\ R Depetris ${ }^{4}$, RW Sanders ${ }^{5}$, WC Koff ${ }^{6}$, JP Moore ${ }^{4}$, AB Ward ${ }^{1}$, DR Burton ${ }^{7}$, IA Wilson ${ }^{8^{*}}$
}

From AIDS Vaccine 2012

Boston, MA, USA. 9-12 September 2012

\section{Background}

Human monoclonal antibodies have been characterized recently that potently neutralize HIV-1 isolates across all clades. These exciting new antibodies (PGT series) were derived from direct functional screening of $B$ cells from IAVI protocol G donors (Theraclone/Monogram) and are unusually potent with binding predicted to be to novel glycan-dependent epitopes on Env.

\section{Methods}

Structures of these new PGT antibodies are being determined by $\mathrm{x}$-ray crystallography and electron microscopy with further characterization using binding and mutagenesis assays.

\section{Results}

The crystal and EM structures so far have been elucidated for many of these antibodies. Work on the others are in progress, focusing on Fab complexes with glycans, gp120 core and fragment constructs, as well as Env trimers.

\section{Conclusion}

Structural characterization and biochemical analysis of these antibodies have uncovered novel specificities to new glycan-dependent epitopes and reveal further mechanisms for viral neutralization. These new epitopes provide additional insights for neutralization of HIV-1 and how antibodies can bind and penetrate the glycan shield, a novel framework for structure-assisted vaccine design.

${ }^{8}$ The Scripps Research Institute, La Jolla, CA, USA

Full list of author information is available at the end of the article
This study was supported by the International AIDS Vaccine Initiative (IAVI), Ragon Institute of MGH, MIT and Harvard, and NIH AI84817.

\section{Author details}

'Dept. of Molecular Biology, The Scripps Research Institute, La Jolla, CA, USA ${ }^{2}$ Dept Imm \& Microbial Sci \& IAVI NAC, The Scripps Research Institute, La Jolla, CA, USA. ${ }^{3}$ The Scripps Research Institute, Ragon Institute MIT, Boston, MA, USA. ${ }^{4}$ Weill Medical College of Cornell University, New York, NY, USA. ${ }^{5}$ Weill Medical College of Cornell University, Academic Medical Center, Amsterdam, the Netherlands. ${ }^{6}$ The International AIDS Vaccine Initiative, New York, NY, USA. ${ }^{7}$ Dept. Imm \& Microbial Sci and IAVI NAC TSRI, Ragon Institute MIT, USA. ${ }^{8}$ The Scripps Research Institute, La Jolla, CA, USA.

Published: 13 September 2012

doi:10.1186/1742-4690-9-S2-P48

Cite this article as: Julien et al:: Recognition and penetration of the HIV1 Env glycan shield by potent broadly neutralizing antibodies.

Retrovirology 2012 9(Suppl 2):P48.

Submit your next manuscript to BioMed Central and take full advantage of:

- Convenient online submission

- Thorough peer review

- No space constraints or color figure charges

- Immediate publication on acceptance

- Inclusion in PubMed, CAS, Scopus and Google Scholar

- Research which is freely available for redistribution

Submit your manuscript at www.biomedcentral.com/submit C Biomed Central 